\title{
Carcinoma of Unknown Primary - an Orphan Disease?
}

\author{
Alwin Krämer ${ }^{\mathrm{a}} \quad$ Gerdt Hübner $^{\mathrm{b}} \quad$ Andreas Schneeweiss $^{\mathrm{c}} \quad$ Gunnar Folprecht $^{\mathrm{d}} \quad$ Kai Neben $^{\mathrm{e}}$ \\ ${ }^{a}$ Klinische Kooperationseinheit für Molekulare Hämatologie und Onkologie des Deutsches Krebsforschungszentrums und der \\ Medizinischen Klinik und Poliklinik V der Universität Heidelberg, \\ bSana Kliniken Ostholstein, Oldenburg, \\ ${ }^{\mathrm{c}}$ Frauenklinik, Universität Heidelberg, \\ ${ }^{\mathrm{d}}$ Medizinische Klinik I, Universität Dresden, \\ ${ }^{\text {e } M e d i z i n i s c h e ~ K l i n i k ~ u n d ~ P o l i k l i n i k ~ V, ~ U n i v e r s i t a ̈ t ~ H e i d e l b e r g, ~ G e r m a n y ~}$
}

\section{Key Words}

CUP . Carcinoma of unknown primary - Metastases . Cetuximab

\section{Summary}

Carcinoma of unknown primary (CUP) is an intriguing clinical finding that is defined as biopsy-proven metastasis from a malignancy in the absence of an identifiable primary site after a complete clinical work-up. CUP is a relatively common clinical entity, accounting for approximately $3-5 \%$ of all cancer diagnoses, and consists of a heterogeneous group of tumors that have acquired the capacity to metastasize before the development of a clinically evident primary lesion. Notable advances have been made over the past years in the treatment of well-defined clinical subgroups of CUP, such as women with peritoneal carcinomatosis and young adults with poorly differentiated carcinomas of midline distribution, but for the majority of patients, the prognosis still remains poor. In this review, we highlight recent advances in the diagnosis and treatment of patients with CUP syndrome, and emphasize the importance of identifying several favorable subsets of CUP, amenable to specific treatment options. In addition, we will point out novel diagnostic and therapeutic approaches which will hopefully improve both our understanding and the prognosis of this more or less neglected disease.

\author{
Schlüsselwörter \\ CUP-Syndrom - Metastasen bei unbekanntem \\ Primärtumor · Metastasen · Cetuximab
}

\section{Zusammenfassung}

Unter dem Cancer of Unknown Primary (CUP)-Syndrom werden diejenigen Tumorerkrankungen zusammengefasst, bei denen auch nach Abschluss der Diagnostik nur Metastasen, jedoch kein Primärtumor gefunden wird. Das CUP-Syndrom macht ca. 3-5\% aller neu diagnostizierten Malignomfälle aus und umfasst eine heterogene Gruppe von Tumoren, die die Fähigkeit zur Metastasierung erlangt haben bevor sich ein klinisch manifester Primärtumor entwickelt hat. Obwohl bemerkenswerte Fortschritte in der Behandlung von Patienten mit bestimmten, gut definierten Erkrankungssubgruppen, wie beispielsweise Frauen mit isolierter Peritonealkarzinose oder jungen Erwachsenen mit gering differenzierten Karzinomen mit Mittellinienverteilung, erzielt werden konnten, ist die Prognose bei der Mehrzahl der Patienten nach wie vor schlecht. Wir berichten im weiteren Verlauf dieser Übersichtsarbeit über Fortschritte in der Diagnostik und Therapie von Patienten mit CUPSyndrom und weisen darauf hin, dass es trotz der immer noch sehr schlechten Prognose von großer Bedeutung ist, Patienten mit bestimmten Subtypen des CUP-Syndroms zu identifizieren, die spezifischen Therapien mit der Option auf Heilung zugeführt werden sollten. Darüber hinaus möchten wir auf neuere diagnostische und therapeutische Bestrebungen aufmerksam machen, die das Verständnis und die Prognose dieses auch in der Onkologie bisher stiefmütterlich behandelten Krankheitsbildes hoffentlich verbessern werden.

\begin{tabular}{ll}
\hline KARGER & @ 2008 S. Karger GmbH, Freiburg \\
Fax +497614520714 & Accessible online at: \\
$\begin{array}{l}\text { E-mail Information@Karger.de } \\
\text { www.karger.com }\end{array}$ & www.karger.com/brc
\end{tabular}




\section{Introduction}

Carcinoma of unknown primary (CUP) is defined as biopsyproven metastasis from a malignancy in the absence of an identifiable primary site after a complete history and physical examination, basic laboratory studies, computed tomography (CT) scans, and additional directed studies indicated by positive findings during the initial work-up [1]. CUP represents $3-5 \%$ of all cancers among males and females, and is slightly more common in men. The median age at diagnosis is 65-70 years. CUP is extremely rare in children. Survival is poor. Empiric chemotherapy with newer, primarily taxane/platinum- or gemcitabine/platinum-based regimens have produced response rates between $30-40 \%$, with 1- and 2-year survivals of approximately 50 and $25 \%$, respectively [2-5]. Complete remissions with these regimens are rare, and the remission duration is usually brief.

A careful and comprehensive pathological examination of biopsied metastatic lesions is crucial for the diagnosis of CUP. Histologically, these tumors can be divided into the following pathological groups [6-9]: i) adenocarcinoma (50-70\%); ii) undifferentiated carcinoma (20-30\%); iii) squamous cell carcinoma $(5-8 \%)$; iv) undifferentiated tumors $(2-3 \%)$. Neuroendocrine carcinoma $(2-4 \%)$ is often mentioned separately because this entity belongs to a treatable subset [10]. Although CUP is a heterogeneous group of tumors with widely diverse natural histories, clinically, they exhibit common typical characteristics: Usually patients present with a short history of nonspecific complaints [11]. The primary tumor remains unidentified throughout life in most cases. Before death, the primary tumor is identified in only $10-20 \%$ of cases despite an extensive radiographic and endoscopic search $[1,12,13]$. In contrast to patients with metastasized known primaries, in whom the percentage of cases with 3 or more organs involved is below $15 \%$ at diagnosis, this number equals approximately $30 \%$ in patients with CUP $[14,15]$. Lastly, an unusual pattern of distant spread has been reported in large autopsy studies $[8,13,16]$.

These findings argue in favor of the hypothesis that CUP comprises a distinct biological disease entity. Nevertheless, there is a long-lasting and still ongoing debate as to whether or not CUP simply reflects metastases shed by a well hidden primary. After evaluation at autopsy, $55-85 \%$ of the primaries are found in patients with CUP. Usually, they are small tumors, most often located in the pancreas (20-26\%) and lung (17-23\%), followed by sites in the colon or rectum (4-10\%), liver (3-11\%), stomach (3-8\%), kidney (4-6\%), ovary $(3-4 \%)$, prostate $(3-4 \%)$, or breast $(2 \%)[1,8]$ (fig. 1$)$.

\section{Diagnostic Evaluation in Carcinomas of Unknown Primary}

When metastatic disease is documented in the absence of a primary site, a careful selection of diagnostic tests is of para-

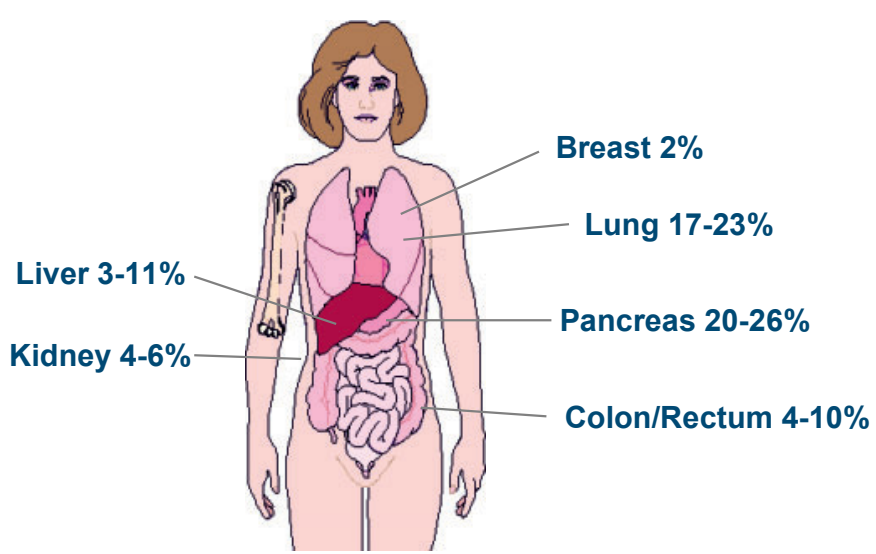

Fig. 1. Primary tumor sites in patients with CUP. The displayed frequencies are derived from historical autopsy studies $[1,8]$.

mount importance to maximize the chances of identifying the primary tumor and additional metastatic sites on the one hand, but to minimize treatment delay, patient risk, and inconvenience and costs associated with a lengthy work-up on the other hand. The basic diagnostic strategy in patients with metastases in the absence of an obvious primary tumor comprises a detailed patient history and physical examination, gynecological examination in women, basic laboratory studies, CT scans of the neck, chest, abdomen, and pelvis, and most importantly - a tumor biopsy. Several recent reviews cover immunohistological strategies applied in order to identify occult primary tumors in CUP patients $[17,18]$. In addition to basic laboratory parameters, the analysis of only a few tumor markers has been proven to have an impact on future therapeutic strategies. Among those are AFP (hepatocellular carcinoma), $\beta$-hCG (germ cell tumors), PSA (prostate cancer), and calcitonin (medullary thyroid carcinoma). Other markers including CEA, Ca125, Ca19-9, and Ca15-3 lack specificity and may serve as follow-up parameters at the most. The role of endoscopy, established in the evaluation of patients with squamous cell carcinoma involving cervical lymph nodes [19], remains incompletely defined in CUP patients not belonging to this favorable clinicopathological subset, and currently appears justified only in patients with clinicopathological characteristics suggesting a primary gastrointestinal or lung carcinoma.

Positron emission tomography with fluorodesoxyglucose (FDG-PET) can be used for the detection of both occult primary tumors and additional metastatic sites in patients with CUP syndrome. With the exception of cervical metastases of unknown primary, PET has only been little explored for CUP patients. However, a recent meta-analysis on 221 patients from 10 studies suggests that in $41 \%$ of patients, a primary tumor site could be identified after conventional diagnostics had failed to do so, although the extent of conventional diagnostics employed was heterogenuous in these studies [20]. In 59\% of the cases, the primary tumor was found in the lungs. Moreover, in $37 \%$ of the patients, addi- 
tional metastatic sites were identified. PET significantly changed the clinical management in approximately one third of the patients studied but had a notably high false-positive rate $(58 \%)$ for tumors of the lower digestive tract. In patients with cervical metastases of unknown primary, the diagnostic value has been more extensively explored. Here, several studies suggest that a primary tumor site can be identified in one third of patients, and the therapeutic strategy is modified in approximately on third of cases as well [21,22]. These preliminary data suggest that PET may have a role in the identification of both occult primary tumors and additional metastases in CUP patients, but additional studies are necessary to further specify its role in this disease entity.

\section{The Importance of Identifying CUP Subsets}

From several studies, it became evident that some patients responded better to specific therapies than others, and treatable subgroups with a better prognosis due to specific treatment were recognized: i) squamous cell carcinoma involving the upper or mid-cervical lymph nodes; ii) squamous cell carcinoma involving the inguinal lymph nodes; iii) women with axillary lymph node metastases; iv) women with peritoneal carcinomatosis; v) men with bone metastases and/or elevated PSA; vi) men with features of extragonadal germ cell tumors; vii) poorly differentiated neuroendocrine tumors; viii) CUP in a single site. Although patients who fit into one of these subsets comprise only a minority of CUP cases, early recognition of these patients is important, because specific treatments can improve outcome, and increase survival. Since several excellent overviews on this topic have been published [23], we here will specifically emphasize only those subgroups with suspected underlying gynecological malignancies.

\section{Squamous Cell Carcinoma Involving the Inguinal Lymph Nodes}

CUP involving the inguinal lymph nodes is rare and accounts for only $1-3.5 \%$ of all CUP cases $[11,24]$. In most patients with inguinal metastases of a squamous cell carcinoma, a primary tumor can be detected in the genital or anorectal area. Identification of a primary site seems especially important in these patients, since carcinomas of the cervix, vagina, vulva, and anus are amenable to curative treatment options even after they have spread to the regional lymph nodes. If no primary site can be identified, inguinal lymph node dissection and/or radiation treatment can result in long-term survival [24]. However, due to the rarity of squamous cell carcinoma of unknown primary involving the inguinal lymph nodes, systematic studies of combined modality therapy have not been published. In a review of 56 cases, local excision alone led to a 5-year survival rate of $33 \%$ [24]. After irradiation alone, a similar 5-year survival rate of $35 \%$ has been reported [24]. These findings suggest that radiation therapy is a valid alternative to surgery in the management of these cases. Based on the patterns of failure following radiation therapy and the fact the primary tumors do only very rarely manifest themselves subsequently in these cases, treating more than the local area of involvement cannot be advocated.

\section{Women with Axillary Lymph Node Metastases}

Metastatic adenocarcinoma involving the axillary lymph nodes in women is highly suggestive for metastatic breast cancer, especially when the cells express HER2 and/or sex hormone receptors [25]. However, hormonal receptors (estrogen and progesterone) are negative in $70-80 \%$ of cases. In these women, the initial work-up should include mammography, breast ultrasound, magnetic resonance imaging (MRI) of the breasts, and PET scanning [26, 27]. MRI of the breast enables the identification of an occult breast primary tumor in about $75 \%$ of women who present with adenocarcinoma in the axillary lymph nodes. The value of PET scanning is more controversial. FDG-PET identified the primary tumor in only about $25 \%$ of these cases [28]. At diagnosis, only $5 \%$ of these patients present with distant metastases [29]. The clinical characteristics of patients with CUP associated with axillary metastasis appear to be comparable to patients with stage II breast cancer. Reports by several groups suggest that the survival rates of patients with $\mathrm{T} 0 \mathrm{~N} 1$ breast cancer may even be higher than those of patients with non-occult stage II breast tumors [30,31].

With regard to treatment, breast surgery and breast irradiation are not recommended if MRI fails to identify a primary breast tumor. Based on data by Vlastos et al. [32], it has been shown that no difference was detected in the rates of locoregional recurrence and distant metastases or 5-year survival between mastectomy and breast preservation in women with occult primary carcinoma presenting with axillary lymph node metastasis. Axillary lymph node dissection is important for histopathological diagnosis, locoregional control, and prognostic information. Analogous to non-occult breast cancer, the most important determinant of survival in CUP with axillary lymph node involvement is the number of positive nodes: 5 -year overall survival was $87 \%$ in patients with $1-3$ positive nodes, compared to $42 \%$ in women with 4 or more positive lymph nodes [32]. In patients with occult primary breast cancer who have undergone axillary lymph node dissection and observation of the breast, breast cancer developed in subsequent years in 14-53\% [31, 33]. In contrast, in women who have received axillary lymph node dissection with subsequent breast irradiation, the incidence of breast cancer development ranged from 12 to $33 \%$ [33-35]. Also, the addition of radiotherapy has been shown to have a signif- 
Table 1. Prospective randomized trials in patients with CUP

\begin{tabular}{|c|c|c|c|c|c|}
\hline Study [reference] & $\begin{array}{l}\text { Patients, } \\
\mathrm{n}\end{array}$ & Chemotherapy regimen & Response rate, \% & $\begin{array}{l}\text { Median PFS, } \\
\text { months }\end{array}$ & $\begin{array}{l}\text { Median OS, } \\
\text { months }\end{array}$ \\
\hline Palmeri et al., 2006 [53] & 66 & $\begin{array}{l}\text { cisplatin + gemcitabine + paclitaxel } \\
\text { vs. cisplatin + gemcitabine + vinorelbine }\end{array}$ & 48.5 vs. 42.3 & NA & 9.6 vs. 13.6 \\
\hline Huebner et al., 2005 [60] & 92 & $\begin{array}{l}\text { carboplatin + paclitaxel vs. } \\
\text { gemcitabine + vinorebine }\end{array}$ & 23.8 vs. 20.0 & 7.0 vs. 3.2 & 11.0 vs. 6.1 \\
\hline Culine et al., 2003 [54] & 80 & $\begin{array}{l}\text { cisplatin + gemcitabine vs. cisplatin } \\
+ \text { irinotecan }\end{array}$ & 55 vs. 38 & 5 vs. 4 & 8 vs. 6 \\
\hline Assersohn et al., 2003 [55] & 88 & 5-FU vs. 5-FU + mitomycin-C & 11.6 vs. 20 (NS) & 4.1 vs. $3.6(\mathrm{NS})$ & 6.6 vs. 4.7 (NS) \\
\hline Dowell et al., 2001 [56] & 34 & $\begin{array}{l}\text { carboplatin + etoposid vs. paclitaxel } \\
+5-\mathrm{FU}+\text { folic acid }\end{array}$ & 19 vs. 19 (NS) & NA & 6.5 vs. $8.4(\mathrm{NS})$ \\
\hline Falkson et al., 1998 [57] & 84 & $\begin{array}{l}\text { cisplatin + epirubicin + mitomycin-C } \\
\text { vs. mitomycin-C }\end{array}$ & 50 vs. 17 & $\begin{array}{l}4.5 \text { vs. } 2.0 \\
(\mathrm{p}=0.05)\end{array}$ & $\begin{array}{l}9.4 \text { vs. } 5.4 \\
(\mathrm{p}=0.05)\end{array}$ \\
\hline Eagan et al., 1987 [2] & 55 & $\begin{array}{l}\text { cisplatin + doxorubicin + mitomycin-C } \\
\text { vs. doxorubicin + mitomycin- } \mathrm{C}\end{array}$ & 27 vs. 14 (NS) & NA & 4.6 vs. 5.5 (NS) \\
\hline Milliken et al., 1987 [58] & 101 & $\begin{array}{l}\text { cisplatin + vinblastin + bleomycin } \\
\text { vs. doxorubicin + mitomycin-C }\end{array}$ & 32 vs. 42 & NA & 6.2 vs. 4.5 (NS) \\
\hline Woods et al., 1980 [59] & 47 & $\begin{array}{l}\text { cyclophosphamide }+ \text { methotrexate } \\
+5 \text {-FU vs. doxorubicin }+ \text { mitomycin-C }\end{array}$ & 5 vs. $36(p<0.01)$ & NA & 1.7 vs. $4.5(\mathrm{NS})$ \\
\hline
\end{tabular}

$\mathrm{CUP}=$ Carcinoma of unknown primary $;$ 5-FU = 5-flurouracil; $\mathrm{NA}=$ not available; $\mathrm{NS}=$ not statistically significant; $\mathrm{PFS}=$ progression-free survival; OS $=$ overall survival.

icant impact on survival in this situation with 91 vs. $43 \%$ surviving with and without radiotherapy, respectively [32]. Thus, breast preservation with radiation treatment might be appropriate in these cases. However, these series of patients have been reported before breast MRI was used on a routine basis. Therefore, it remains unclear whether these results apply to patients with a normal breast MRI. Adjuvant chemotherapy and endocrine therapy protocols should follow the guidelines for stage II breast cancer. In patients with $\mathrm{N} 2$ disease, neoadjuvant chemotherapy in analogy to breast cancer treatment is recommended.

\section{Women with Peritoneal Carcinomatosis}

Adenocarcinoma causing diffuse peritoneal involvement in women, usually originates in the ovary, although primaries in breast or gastrointestinal tract may occasionally produce this syndrome. Histological features like papillary configuration or psammoma bodies are suggestive for ovarian carcinoma. In these cases, the syndrome has been termed 'multifocal extraovarian serous carcinoma' or 'peritoneal papillary serous carcinoma'. However, some patients have poorly differentiated carcinoma, resembling poorly differentiated epithelial ovarian carcinoma. These patients should be treated according to the guidelines for stage III ovarian cancer, including initial maximal surgical cytoreduction, followed by a taxane/platinum-based chemotherapy [36].

\section{Carcinoma of Unknown Primary in a Single Site}

Approximately one third of the patients presenting with CUP have a unique metastatic site. The most frequent locations are liver, bones, lungs, and lymph nodes [37,38]. Median survival is 20 months in patients with localized CUP as compared to 7 months in cases that presented with disseminated disease [39]. In addition to standard diagnostic procedures, a PET scan might be specifically helpful in this patient group, primarily to exclude additional metastatic sites [40]. In most patients presenting with a single metastatic lesion, other metastatic sites become apparent within a relatively short time. However, definitive local treatment sometimes produces prolonged diseasefree intervals. Moreover, occasionally, patients have prolonged survival. Therefore, resection of the solitary lesion should be undertaken if feasible. In addition, postoperative irradiation seems appropriate to maximize the likelihood of local control $[41,42]$. With regard to additional adjuvant chemotherapy, systematic studies proving its superiority as compared to local treatment alone are lacking. Accordingly, such a strategy cannot be recommended until more data support this concept.

\section{Treatment of Patients with Carcinoma of Unknown Primary}

Although several clinicopathologic subsets with a favorable prognosis have been identified, most patients do not fit into 


\section{Study Design \\ Randomized Phase III Study}

Patients with newly diagnosed disseminated CUP

Histology: undifferentiated or adenocarcinoma

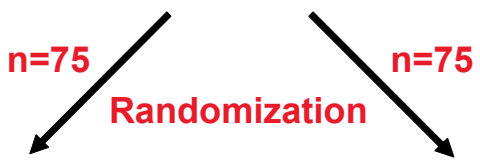

\section{$6 \times$ Carboplatin + Paclitaxel}

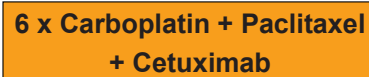

Fig. 2. Concept of a prospective, randomized trial comparing the current treatment standard carboplatin/paclitaxel with carboplatin/paclitaxel plus cetuximab in patients with newly diagnosed adeno- or undifferentiated CUP syndrome.

any of these subgroups. About $50-70 \%$ of CUP patients suffer from disseminated adeno- or undifferentiated carcinoma, where local treatment strategies are not an option. Five prospective phase II trials by the Minnie Pearl Cancer Research Network analyzing different platinum/taxane combinations established a total response rate of $30 \%$, with $94 \%$ partial responders and $6 \%$ complete responders, a median survival of 9.1 months, 1 - and 5-year survivals of 38 and $8 \%$, and 1- and 5-year progression-free survivals of 17 and $4 \%$, respectively $[5,43-46]$. Importantly, no difference in survival with any of the combinations used, or between poorly differentiated and adenocarcinomas, was found.

Randomized prospective trials proving that any form of chemotherapy improves the survival of CUP patients with disseminated adeno- or undifferentiated carcinoma over best supportive care alone are lacking. Nevertheless, comparison with historical data from large patient collections $[6,7,9,47-52]$ which show 1- and 5-year survival rates of 20 and $5 \%$, respectively, demonstrates that newer taxane/ platinum-based chemotherapy regimens have led to a significant improvement of survival. Only very few randomized clinical trials comparing different chemotherapy regimens to each other have been reported for CUP patients at all [2, 53-60]. These are summarized in table 1 and basically support the view that platinum-based regimens are superior to combinations without platinum. Therefore, the standard chemotherapy for good performance status CUP patients with disseminated adeno- or undifferentiated carcinoma nowadays consists of a taxane/platinum combination. Because of the lower toxicity of carboplatin as compared to cisplatin, the favored regimen is carboplatin/paclitaxel. With this combination, response rates of $30-40 \%$ and a 2 -year survival rate of $20-25 \%$ can be achieved if administered as first-line therapy.

Only a few second-line chemotherapy regimens for patients with CUP have been evaluated, and these have produced low

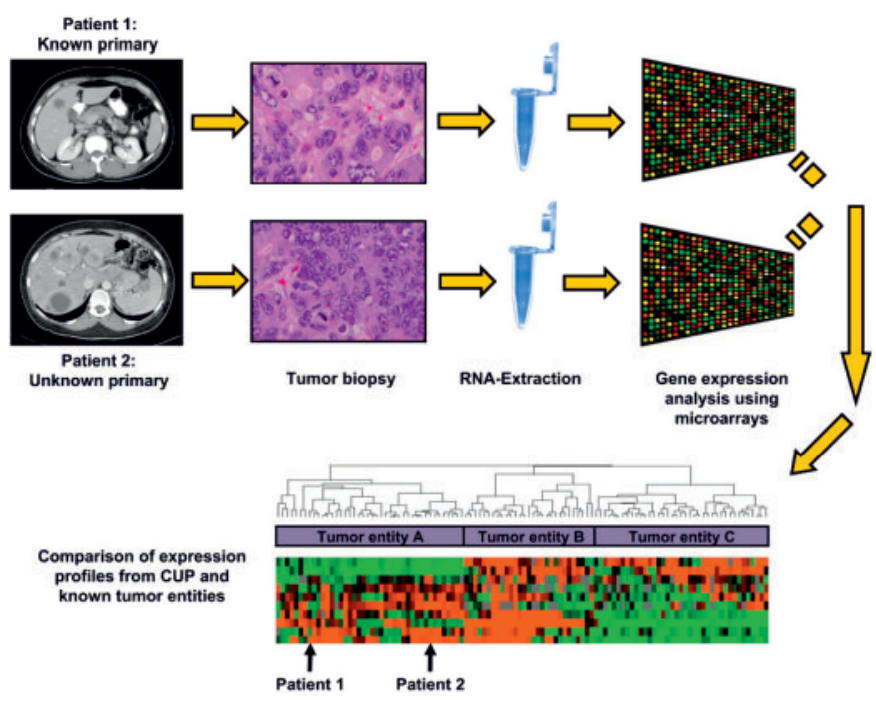

Fig. 3. Outline of the gene expression analysis procedure using tumor biopsy samples from patients treated in the prospective randomized trial as depicted in figure 2. The expression profiles of the analyzed samples will be compared with gene expression profiles from tumors with known primary sites.

response rates. During recent years, single agent gemcitabine and the combination of gemcitabine with irinotecan has been evaluated as a second-line treatment in patients with CUP $[61,62]$. Although both treatments had modest activity, response rates of only 8 and $10 \%$ were achieved, and median survival was short (3 and 4.5 months, respectively). Taken together, although CUP patients with disseminated adenoor undifferentiated carcinoma certainly attain clinical benefit and prolonged survival from modern chemotherapy regimens, there is an urgent need for improvement, both in first- and second-line treatment strategies.

Analogous to several other tumor entities, progress in the treatment of patients with CUP might come from the use of agents with novel mechanisms of action. Although data on CUP biology including mutation status and expression levels of oncogenes and tumor suppressors are scarce, it has recently been reported that, in contrast to HER2 and c-Kit which were detected in only 4 and $10 \%$ of CUP patients, respectively, the epidermal growth factor receptor (EGFR) is expressed in $66 \%$ of CUP tumors [63]. Of note, EGFR expression was correlated to tumor chemosensitivity towards platinum-based chemotherapy in this study. Also, recent data show that in a group of predominantly pretreated patients with mostly disseminated adeno- or undifferentiated carcinoma, a combination of erlotinib and bevacizumab which target EGFR and vascular endothelial growth factor (VEGF), respectively, leads to a median survival of 7.4 months and a 1-year survival rate of 33\% [64], which appears substantially improved when compared retrospectively with other second-line regimens and, in fact, is similar to the survival reported for many first-line chemotherapies. 
Derived from these data, the CUP working group of the German Cancer Society has decided to add the anti-EGFR antibody cetuximab which has been shown to be effective in colorectal, head and neck, and non-small cell lung cancer [65-68] to the current standard chemotherapy regimen carboplatin/paclitaxel, and to compare its efficacy with carboplatin/paclitaxel chemotherapy alone in a prospective, randomized trial (fig. 2). In addition, this study will include molecular profiling analyses at both the genomic and the expression level (fig. 3). This will hopefully result in a deepened understanding of the biology and the identification of novel molecular targets for the treatment of this up to now more or less neglected disease.

\section{Acknowledgments}

We would like to thank Prof. Dr. Michael Stahl and Dr. Albrecht Kretschmar on behalf of the CUP study group of the German Cancer Society for their thoughtful comments on the manuscript and their contributions to the planned prospective, randomized clinical trial.

\section{References}

$\checkmark 1$ Abbruzzese JL, Abbruzzese MC, Lenzi R, Hess KR, Raber MN: Analysis of a diagnostic strategy for patients with suspected tumors of unknown origin. J Clin Oncol 1995;13:2094-2103.

$\checkmark 2$ Eagan RT, Therneau TM, Rubin J, Long HJ, Schutt AJ: Lack of value for cisplatin added to mitomycin-doxorubicin combination chemotherapy for carcinoma of unknown primary site. A randomized trial. Am J Clin Oncol 1987;10:82-85.

$>3$ Goldberg RM, Smith FP, Ueno W, Ahlgren JD, Schein PS: 5-fluorouracil, adriamycin, and mitomycin in the treatment of adenocarcinoma of unknown primary. J Clin Oncol 1986;4:395-399.

4 Greco FA, Burris HA 3rd, Erland JB, Gray JR, Kalman LA, Schreeder MT, Hainsworth JD: Carcinoma of unknown primary site. Cancer 2000; 89:2655-2660

$\checkmark 5$ Greco FA, Gray J, Burris HA 3rd, Erland JB, Morrissey LH, Hainsworth JD: Taxane-based chemotherapy for patients with carcinoma of unknown primary site. Cancer J 2001;7:203-212.

6 Altman E, Cadman E: An analysis of 1539 patients with cancer of unknown primary site. Cancer 1986;57:120-124.

7 Hess KR, Abbruzzese MC, Lenzi R, Raber MN Abbruzzese JL: Classification and regression tree analysis of 1000 consecutive patients with unknown primary carcinoma. Clin Cancer Res 1999; 5:3403-3410.

8 Le Chevalier T, Cvitkovic E, Caille P, Harvey J, Contesso G, Spielmann M, Rouesse J: Early metastatic cancer of unknown primary origin at presentation. A clinical study of 302 consecutive autopsied patients. Arch Internal Med 1988;148: 2035-2039.

$\checkmark 9$ Van de Wouw AJ, Janssen-Heijnen ML, Coebergh JW, Hillen HF: Epidemiology of unknown primary tumours; incidence and population-based survival of 1285 patients in Southeast Netherlands, 19841992. Eur J Cancer 2002;38:409-413.

10 Hainsworth JD, Spigel DR, Litchy S, Greco FA: Phase II trial of paclitaxel, carboplatin, and etoposide in advanced poorly differentiated neuroendocrine carcinoma: a Minnie Pearl Cancer Research Network Study. J Clin Oncol 2006;24: 3548-3554.

-11 Didolkar MS, Fanous N, Elias EG, Moore RH: Metastatic carcinomas from occult primary tumors. A study of 254 patients. Ann Surg 1977;186 625-630.

12 Hainsworth JD, Johnson DH, Greco FA: Poorly differentiated neuroendocrine carcinoma of unknown primary site. A newly recognized clinicopathologic entity. Ann Internal Med 1988;109: 364-371.
13 Nystrom JS, Weiner JM, Heffelfinger-Juttner J, Irwin LE, Bateman JR, Wolf RM: Metastatic and histologic presentations in unknown primary cancer. Sem Oncol 1977;4:53-58.

14 Culine S, Kramar A, Saghatchian M, Bugat R, Lesimple T, Lortholary A, Merrouche Y, Laplanche A, Fizazi K: Development and validation of a prognostic model to predict the length of survival in patients with carcinomas of an unknown primary site. J Clin Oncol 2002;20:46794683.

15 Van de Wouw AJ, Jansen RL, Griffioen AW, Hillen HF: Clinical and immunohistochemical analysis of patients with unknown primary tumour. A search for prognostic factors in UPT. Anticancer Res 2004;24:297-301.

16 Mayordomo JI, Guerra JM, Guijarro C, GarciaPrats MD, Gomez A, Lopez-Brea M, Gonzalez R, Hergueta P, Lopez-Pino MA, Martinez-Tello F, et al.: Neoplasms of unknown primary site: a clinicopathological study of autopsied patients. Tumori 1993;79:321-324.

17 Kaufmann O, Fietze E, Dietel M: Immunohistochemical diagnosis in cancer metastasis of unknown primary tumor. Pathologe 2002;23:183-197.

18 Voigt JJ, Mathieu MC, Bibeau F: The advent of immunohistochemistry in carcinoma of unknown primary site: a major progress; in Fizazi K (ed): Carcinoma of an Unknown Primary Site. New York, Taylor and Francis, 2006, pp. 25-35.

19 Bugat R, Bataillard A, Lesimple T, Voigt JJ, Culine S, Lortholary A, Merrouche Y, Ganem G, Kaminsky MC, Negrier S, Perol M, Laforet C, Bedossa P, Bertrand G, Coindre JM, Fizazi K: Summary of the standards, options and recommendations for the management of patients with carcinoma of unknown primary site (2002). Brit J Cancer 2003;89:S59-66.

20 Seve P, Billotey C, Broussolle C, Dumontet C, Mackey JR: The role of 2-deoxy-2-[F-18]fluoro-Dglucose positron emission tomography in disseminated carcinoma of unknown primary site. Cancer 2007;109:292-299.

21 Bohuslavizki KH, Klutmann S, Kroger S, Sonnemann U, Buchert R, Werner JA, Mester J, Clausen M: FDG PET detection of unknown primary tumors. J Nucl Med 2000;41:816-822.

22 Regelink G, Brouwer J, de Bree R, Pruim J, van der Laan BF, Vaalburg W, Hoekstra OS, Comans EF, Vissink A, Leemans CR, Roodenburg JL: Detection of unknown primary tumours and distant metastases in patients with cervical metastases: value of FDG-PET versus conventional modalities. Eur J Nucl Med Mol Imag 2002;29:1024-1030.
23 Fizazi K: Carcinoma of an Unknown Primary Site. New York, Taylor and Francis, 2006.

24 Guarischi A, Keane TJ, Elhakim T: Metastatic inguinal nodes from an unknown primary neoplasm. A review of 56 cases. Cancer 1987;59:572-577.

25 Bhatia SK, Saclarides TJ, Witt TR, Bonomi PD, Anderson KM, Economou SG: Hormone receptor studies in axillary metastases from occult breast cancers. Cancer 1987;59:1170-1172.

26 Schorn C, Fischer U, Luftner-Nagel S, Westerhof JP, Grabbe E: MRI of the breast in patients with metastatic disease of unknown primary. Eur Radiol 1999;9:470-473.

27 Block EF, Meyer MA: Positron emission tomography in diagnosis of occult adenocarcinoma of the breast. Am Surgeon 1998;64:906-908.

28 Kole AC, Nieweg OE, Pruim J, Hoekstra HJ, Koops HS, Roodenburg JL, Vaalburg W, Vermey A: Detection of unknown occult primary tumors using positron emission tomography. Cancer 1998; 82:1160-1166.

29 Jackson B, Scott-Conner C, Moulder J: Axillary metastasis from occult breast carcinoma: diagnosis and management. Am Surgeon 1995;61:431-434.

30 Rosen PP, Kimmel M: Occult breast carcinoma presenting with axillary lymph node metastases: a follow-up study of 48 patients. Hum Pathol 1990; 21:518-523.

31 Van Ooijen B, Bontenbal M, Henzen-Logmans SC, Koper PC: Axillary nodal metastases from an occult primary consistent with breast carcinoma. Brit J Surg 1993;80:1299-1300.

32 Vlastos G, Jean ME, Mirza AN, Mirza NQ, Kuerer HM, Ames FC, Hunt KK, Ross MI, Buchholz TA, Buzdar AU, Singletary SE: Feasibility of breast preservation in the treatment of occult primary carcinoma presenting with axillary metastases. Ann Surg Oncol 2001;8:425-431.

33 Merson M, Andreola S, Galimberti V, Bufalino R, Marchini S, Veronesi U: Breast carcinoma presenting as axillary metastases without evidence of a primary tumor. Cancer 1992;70:504-508.

34 Campana F, Fourquet A, Ashby MA, Sastre X, Jullien D, Schlienger P, Labib A, Vilcoq JR: Presentation of axillary lymphadenopathy without detectable breast primary (T0 N1b breast cancer): experience at Institut Curie. Radiotherapy Oncol 1989;15:321-325.

35 Vilcoq JR, Calle R, Ferme F, Veith F: Conservative treatment of axillary adenopathy due to probable subclinical breast cancer. Arch Surg 1982; 117:1136-1138 
\36 McGuire WP, Hoskins WJ, Brady MF, Kucera PR, Partridge EE, Look KY, Clarke-Pearson DL, Davidson M: Cyclophosphamide and cisplatin compared with paclitaxel and cisplatin in patients with stage III and stage IV ovarian cancer. N Eng J Med 1996;334:1-6.

-37 Abbruzzese JL, Abbruzzese MC, Hess KR, Raber MN, Lenzi R, Frost P: Unknown primary carcinoma: natural history and prognostic factors in 657 consecutive patients. J Clin Oncol 1994;12: 1272-1280.

-38 Pavlidis N, Briasoulis E, Hainsworth J, Greco FA Diagnostic and therapeutic management of cancer of an unknown primary. Eur J Cancer 2003;39: 1990-2005.

39 Hübner G, Wildfang I, Schmoll HJ: CUP, in Schmoll HJ (ed): Kompendium Internistische Onkologie, Band 2. Berlin, Springer, 1999, pp. 2137-2181.

40 Rades D, Kuhnel G, Wildfang I, Borner AR, Schmoll HJ, Knapp W: Localised disease in cancer of unknown primary (CUP): the value of positron emission tomography (PET) for individual therapeutic management. Ann Oncol 2001;12:16051609 .

41 Nguyen LN, Maor MH, Oswald MJ: Brain metastases as the only manifestation of an undetected primary tumor. Cancer 1998;83:2181-2184.

42 Salvati M, Cervoni L, Raco A: Single brain metastases from unknown primary malignancies in CTera. J Neuro Oncol 1995;23:75-80.

43 Hainsworth JD, Erland JB, Kalman LA, Schreeder MT, Greco FA: Carcinoma of unknown primary site: treatment with 1-hour paclitaxel, carboplatin, and extended-schedule etoposide. J Clin Oncol 1997; 15:2385-2393.

44 Greco FA, Erland JB, Morrissey LH, Burris HA, 3rd, Hermann RC, Steis R, Thompson D, Gray J, Hainsworth JD: Carcinoma of unknown primary site: phase II trials with docetaxel plus cisplatin or carboplatin. Ann Oncol 2000;11:211-215.

45 Greco FA, Burris HA 3rd, Litchy S, Barton JH, Bradof JE, Richards P, Scullin DC, Jr., Erland JB, Morrissey LH, Hainsworth JD: Gemcitabine, carboplatin, and paclitaxel for patients with carcinoma of unknown primary site: a Minnie Pearl Cancer Research Network study. J Clin Oncol 2002;20:1651-1656.

46 Greco FA, Hainsworth JD, Yardley DA: Sequential paclitaxel/carboplatin/etoposide followed by irinotecan/gemcitabine for patients with carcinoma of unknown primary site: a Minnie Pearl Cancer Research Network phase II trial. Proc Am Soc Clin Oncol 2002;21:161a.

47 Holmes FF, Fouts TL: Metastatic cancer of unknown primary site. Cancer 1970;26:816-820.
48 Krementz ET, Cerise EJ, Foster DS, Morgan LR Jr: Metastases of undetermined source. Curr Problems Cancer 1979;4:4-37.

49 Markman M: Metastatic adenocarcinoma of unknown primary site: analysis of 245 patients seen at The Johns Hopkins Hospital from 1965-1979. Med Pediat Oncol 1982;10:569-574.

50 Moertel CG, Reitemeier RJ, Schutt AJ, Hahn RG: Treatment of the patient with adenocarcinoma of unknown origin. Cancer 1972;30:1469-1472.

51 Levi F, Te VC, Erler G, Randimbison L, La Vecchia C: Epidemiology of unknown primary tumours. Eur J Cancer 2002;38:1810-1812.

52 Muir C: Cancer of unknown primary site. Cancer 1995;75:353-356.

53 Palmeri S, Lorusso V, Palmeri L, Vaglica M, Porta C, Nortilli R, Ferrau F, Comella G, Massidda B, Danova M: Cisplatin and gemcitabine with either vinorelbine or paclitaxel in the treatment of carcinomas of unknown primary site : results of an Italian multicenter, randomized, phase II study. Cancer 2006;107:2898-2905.

54 Culine S, Lortholary A, Voigt JJ, Bugat R, Theodore C, Priou F, Kaminsky MC, Lesimple T, Pivot X, Coudert B, Douillard JY, Merrouche Y, Allouache J, Goupil A, Negrier S, Viala J, Petrow P, Bouzy J, Laplanche A, Fizazi K: Cisplatin in combination with either gemcitabine or irinotecan in carcinomas of unknown primary site: results of a randomized phase II study trial for the French Study Group on Carcinomas of Unknown Primary (GEFCAPI 01). J Clin Oncol 2003;21:3479-3482.

55 Assersohn L, Norman AR, Cunningham D, Iveson T, Seymour M, Hickish T, Massey A, Prior Y, Hill ME: A randomised study of protracted venous infusion of 5-fluorouracil (5-FU) with or without bolus mitomycin $\mathrm{C}$ (MMC) in patients with carcinoma of unknown primary. Eur J Cancer 2003; 39:1121-1128.

56 Dowell JE, Garrett AM, Shyr Y, Johnson DH, Hande KR: A randomized Phase II trial in patients with carcinoma of an unknown primary site. Cancer 2001;91:592-597.

57 Falkson CI, Cohen GL: Mitomycin C, epirubicin and cisplatin versus mitomycin $\mathrm{C}$ alone as therapy for carcinoma of unknown primary origin. Oncol 1998;55:116-121

58 Milliken ST, Tattersall MH, Woods RL, Coates AS, Levi JA, Fox RM, Raghavan D: Metastatic adenocarcinoma of unknown primary site. A randomized study of two combination chemotherapy regimens. Eur J Cancer Clin Oncol 1987;23:16451648 .

59 Woods RL, Fox RM, Tattersall MH, Levi JA, Brodie GN: Metastatic adenocarcinomas of unknown primary site: a randomized study of two combination-chemotherapy regimens. N Eng J Med 1980;303:87-89.
60 Huebner G, Steinbach S, Kohne CH, Stahl M, Kretzschmar A, Eimermacher A, Link H on behalf of the Germann CUP Study Group: Paclitaxel $(\mathrm{P})$ /carboplatin $(\mathrm{C})$ versus gemcitabine $(\mathrm{G})$ /vinorelbine $(\mathrm{V})$ in patients with adeno- or undifferentiated carcinoma of unknown primary (CUP) - a randomized prospective phase-II-trial. Proc Am Soc Clin Oncol 2005;23:330s.

61 Hainsworth JD, Burris HA 3rd, Calvert SW, Willcutt NT, Scullin DC Jr, Bramham J, Greco FA Gemcitabine in the second-line therapy of patients with carcinoma of unknown primary site: a phase II trial of the Minnie Pearl Cancer Research Network. Cancer Invest 2001;19:335-339.

62 Hainsworth JD, Spigel DR, Raefsky EL, Kuzur ME, Yost K, Kommor M, Litchy S, Greco FA: Combination chemotherapy with gemcitabine and irinotecan in patients with previously treated carcinoma of an unknown primary site: a Minnie Pearl Cancer Research Network Phase II trial. Cancer 2005;104:1992-1997.

63 Massard C, Voigt JJ, Laplanche A, Culine S, Lortholary A, Bugat R, Theodore C, Priou F, Kaminsky MC, Lesimple T, Pivot X, Coudert B, Douillard JY, Merrouche Y, Fizazi K: Carcinoma of an unknown primary: are EGF receptor, Her-2/neu, and c-Kit tyrosine kinases potential targets for therapy? Brit J Cancer 2007;97:857861.

64 Hainsworth JD, Spigel DR, Farley C, Thompson DS, Shipley DL, Greco FA: Phase II trial of bevacizumab and erlotinib in carcinomas of unknown primary site: the Minnie Pearl Cancer Research Network. J Clin Oncol 2007;25:1747-1752.

65 Cunningham D, Humblet Y, Siena S, Khayat D, Bleiberg H, Santoro A, Bets D, Mueser M, Harstrick A, Verslype C, Chau I, Van Cutsem E: Cetuximab monotherapy and cetuximab plus irinotecan in irinotecan-refractory metastatic colorectal cancer. N Eng J Med 2004;351:337-345

66 Vermorken JB, Trigo J, Hitt R, Koralewski P, DiazRubio E, Rolland F, Knecht R, Amellal N, Schueler A, Baselga J: Open-label, uncontrolled, multicenter phase II study to evaluate the efficacy and toxicity of cetuximab as a single agent in patients with recurrent and/or metastatic squamous cell carcinoma of the head and neck who failed to respond to platinum-based therapy. J Clin Oncol 2007;25:2171-2177.

67 Giaccone G: Epidermal growth factor receptor inhibitors in the treatment of non-small-cell lung cancer. J Clin Oncol 2005;23:3235-3242.

68 Morgensztern D, Govindan R: Is there a role for cetuximab in non small cell lung cancer? Clin Cancer Res 2007;13:s4602-4605. 